\title{
Microwave antigen retrieval in immunocytochemistry: a study of 80 antibodies
}

E C Cuevas, A C Bateman, B S Wilkins, P A Johnson, J H Williams, A H S Lee, D B Jones, D H Wright

\begin{abstract}
Aims-To evaluate the effect of microwave irradiation on the staining quality of a range of commonly used primary antibodies in archival, formalin fixed, paraffin wax embedded material, with emphasis on antibodies that have previously worked successfully only on frozen tissue.

Methods-Immunocytochemistry (streptavidin-biotin complex technique) was performed on histological sections of a range of normal and pathological tissues, after varying treatment with microwave irradiation. The staining quality of each antibody was compared with that achieved without prior treatment of the sections or after enzyme predigestion.

Results-Microwave irradiation permitted successful immunostaining with 20 antibodies that stained only frozen tissues before. The staining characteristics of 21 antibodies that were already known to stain formalin fixed, paraffin wax embedded material were improved. Another 39 antibodies did not show enhanced staining with microwave irradiation. The method preserves tissue morphology and produces more consistent staining than that achieved by enzyme predigestion with many antibodies. Microwave irradiation may also allow some primary antibodies to be used at higher working dilutions. The citrate
\end{abstract}

Table 1 Monoclonal antibodies previously not reactive with formalin fixed, paraffin wax embedded tissue, which work well after microwave irradiation

\begin{tabular}{|c|c|c|}
\hline Antibody & $C D /$ specificity & Source \\
\hline \multicolumn{3}{|c|}{ Lymphocytic and myelomonocytic markers } \\
\hline $\begin{array}{l}\text { E11 } \\
\text { AT13/5 } \\
\text { TÜ69 } \\
\text { WR16 }\end{array}$ & $\begin{array}{l}\text { CD35 } \\
\text { CD38 } \\
\text { CD25 } \\
\text { CD45R }\end{array}$ & $\begin{array}{l}\text { K Gatter, Oxford } \\
\text { A Tutt, Tenovus, Southampton } \\
\text { A Ziegler, Berlin } \\
\text { Wessex Regional Immunology } \\
\text { Unit }\end{array}$ \\
\hline IB5 & MHC class II & ICRF \\
\hline IgD & IgD & Dako \\
\hline QBEND 10 & CD34 & Novocastra \\
\hline $\begin{array}{l}\text { EBM } 11 \\
\text { CD5 }\end{array}$ & $\begin{array}{l}\text { CD68 } \\
\text { CD5 }\end{array}$ & $\begin{array}{l}\text { K Gatter, Oxford } \\
\text { K Gatter, Oxford }\end{array}$ \\
\hline CD8 & CD8 & K Gatter, Oxford 9 \\
\hline STCS & Human $\gamma \delta$ TCR & Becton Dickinson \\
\hline $\begin{array}{l}\text { BRIC } 128 \\
\text { Proliferation markers }\end{array}$ & CD55 & D Anstee, NBTS, Bristol ${ }^{15}$ \\
\hline MIB 1 & Ki-67 antigen & \multirow{2}{*}{$\begin{array}{l}\text { J Gerdes, Forschungsinstitut } \\
\text { Borstel, Germany } \\
\text { K Gatter, Oxford } \\
\text { J Gerdes, Forschungsinstitut }_{\text {Borstel, Germany }{ }^{17}}\end{array}$} \\
\hline $\begin{array}{l}\text { JC1 } \\
\text { Ki-67 }\end{array}$ & $\begin{array}{l}\text { Proliferation marker } \\
\text { Ki-67 antigen }\end{array}$ & \\
\hline $\begin{array}{l}\text { Adhesion molecules } \\
1 \cdot 4 \mathrm{C} 3 \\
\text { BRIC } 235 \\
\text { 2H1 } \\
\text { IF1 } \\
\text { IE8 }\end{array}$ & $\begin{array}{l}\text { VCAM-1 } \\
\text { CD44 } \\
\text { CD44 } \\
\text { CD44 } \\
\text { CD44 }\end{array}$ & $\begin{array}{l}\text { D Haskard, Hammersmith } \\
\text { D Anstee, NBTS, Bristol }{ }^{15} \\
\text { S Jalkenen, Turku, Finland } \\
\text { S Jalkenen, Turku, Finland } \\
\text { S Jalkenen, Turku, Finland }\end{array}$ \\
\hline
\end{tabular}

buffer used in this study avoids the necessity of exposure to heavy metal salts. Conclusions-Microwave antigen retrieval represents an important technical advance within immunocytochemistry that will greatly increase the range of antibodies which can be used to study formalin fixed, paraffin wax embedded tissues.

\section{(f Clin Pathol 1994;47:448-452)}

Microwave irradiation has been used to improve tissue fixation, ${ }^{1-2}$ to enhance histological staining for light and electron microscopy, ${ }^{3-4}$ and, more recently, to enhance immunocytochemical staining..$^{5-10}$ The latter technique is becoming increasingly popular and has several advantages over conventional methods such as enzymatic predigestion. ${ }^{11} \mathrm{Sh}$ et al have documented a range of antibodies in which performance in fixed tissue sections was improved by microwave irradiation. Many of the antibodies they investigated, however, were already known to be active in fixed tissue. The purpose of the present study was to extend the use of the technique specifically to antibodies previously found to react only with frozen sections or cytological preparations.

\section{Methods}

Eighty antibodies were studied, consisting of 47 reactive with lymphohistiocytic antigens, 20 reactive with cell adhesion molecules, four proliferation markers, and nine other antibodies directed against miscellaneous antigens. All except the CD3 reagent were monoclonal antibodies. A range of normal tissues (lymph node, tonsil, spleen, bone marrow, small bowel) and tissues showing a variety of pathologies (glomerulonephritis, Hashimoto's thyroiditis, Hodgkin's and non-Hodgkin's lymphomas, cerebral astrocytomas, sarcoidosis, Crohn's disease) were studied. All material, obtained from the files of the Department of Pathology at Southampton General Hospital, was fixed in $10 \%$ neutral buffered formalin and embedded in paraffin wax using routine methods.

Tissue sections were cut at $5 \mu \mathrm{m}$ on to slides coated with poly L-lysine (PLL) or 3aminopropyltriethoxysilane (APTS). Endogenous peroxidase was inhibited with $0.5 \%$ $\mathrm{H}_{2} \mathrm{O}_{2}$ in methanol for 10 minutes, followed by a single wash in TRIS-buffered saline (TBS). 
Five slides were placed in a plastic Coplin jar, filled with citrate buffer $^{7-8}(2 \cdot 1 \mathrm{~g}$ citric acid monohydrate in 1 litre of distilled water, $\mathrm{pH}$ $6.0)$ and covered with perforated cling film to minimise evaporation. Three Coplin jars were placed, evenly spaced, in a domestic microwave oven (Panasonic NN-6450, $800 \mathrm{~W}$ ) and irradiated for five minutes at medium power. Evaporative fluid loss was replaced with fresh buffer and this cycle was repeated up to three times. After microwave irradiation the slides were allowed to cool to room temperature and incubation with pri-

Figure 1 Examples of antibodies that previously showed no reactivity in formalin fixed, paraffin wax embedded material, but gave good results after microwave irradiation. (A) Staining quality with (right) and without (left) microwave pre-treatment: (i) MIB 1, tonsil;

(ii) CD44, thyroid;

(iii) $C D 8$, tonsil.
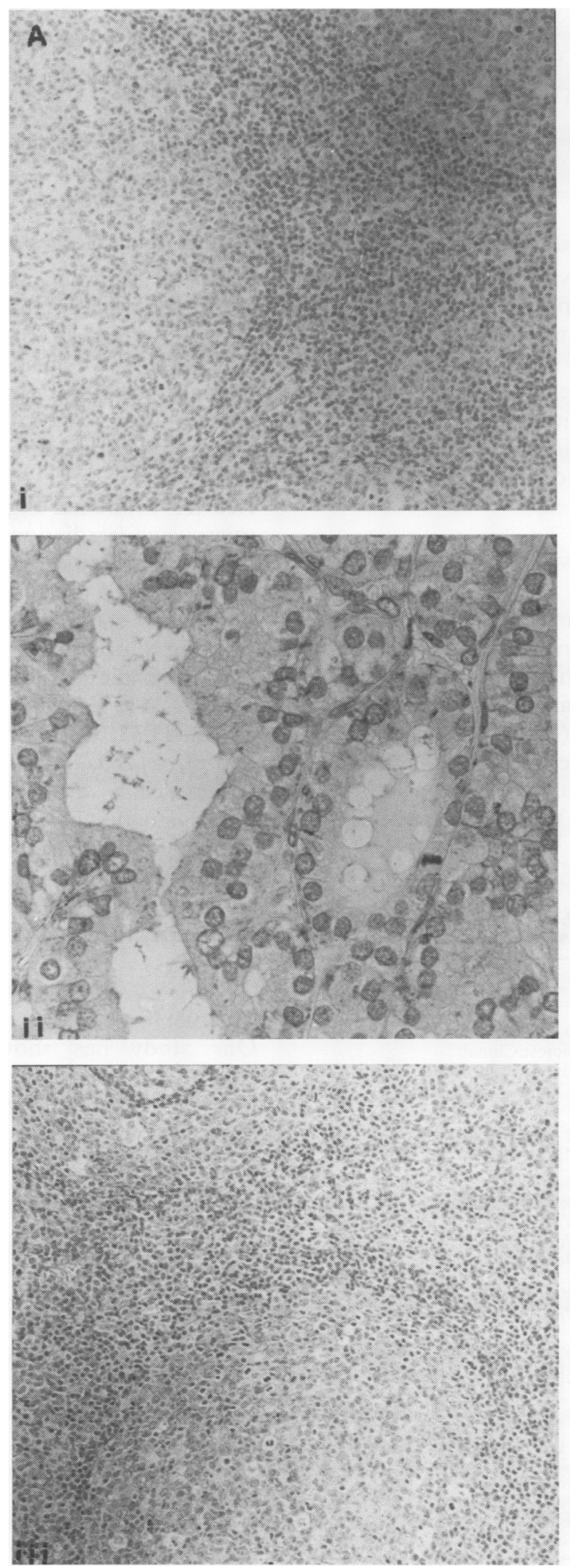
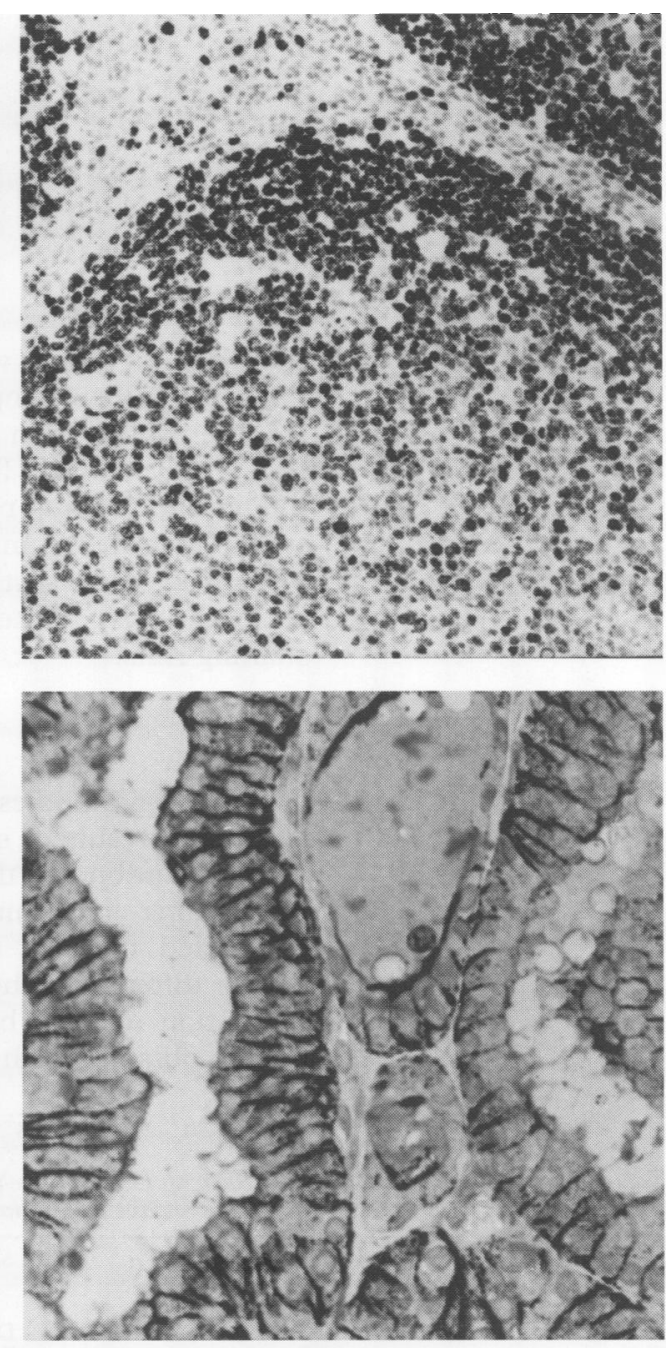

mary antibody was then performed at $4^{\circ} \mathrm{C}$ for 18-24 hours. In some cases a short digestion step with trypsin $(0.1 \%$ trypsin [Sigma T8128] in $0.1 \% \mathrm{CaCl}_{2}$ at $\mathrm{pH} 7.8,37^{\circ} \mathrm{C}$ ) was included after microwave irradiation and before the application of primary antibody. Bound primary antibodies were visualised using a peroxidase-labelled streptavidin-biotin complex method, with 3,3-diaminobenzidine as the chromogen. ${ }^{12}$

All antibodies were tested with and without microwave irradiation, and the staining quality was compared with that acheived using a

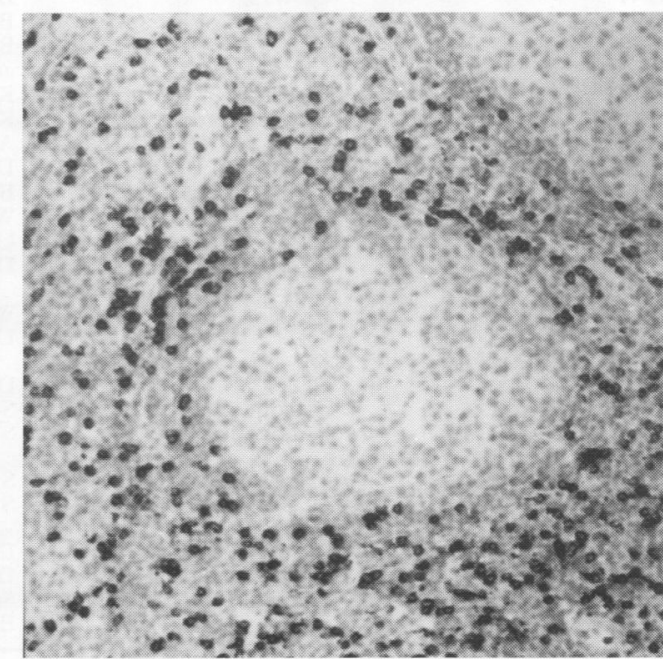


(B) MIB 1 staining in enteropathy associated $T$ cell lymphoma (left), Burkitt's lymphoma (centre), and Hodgkin's disease (right)
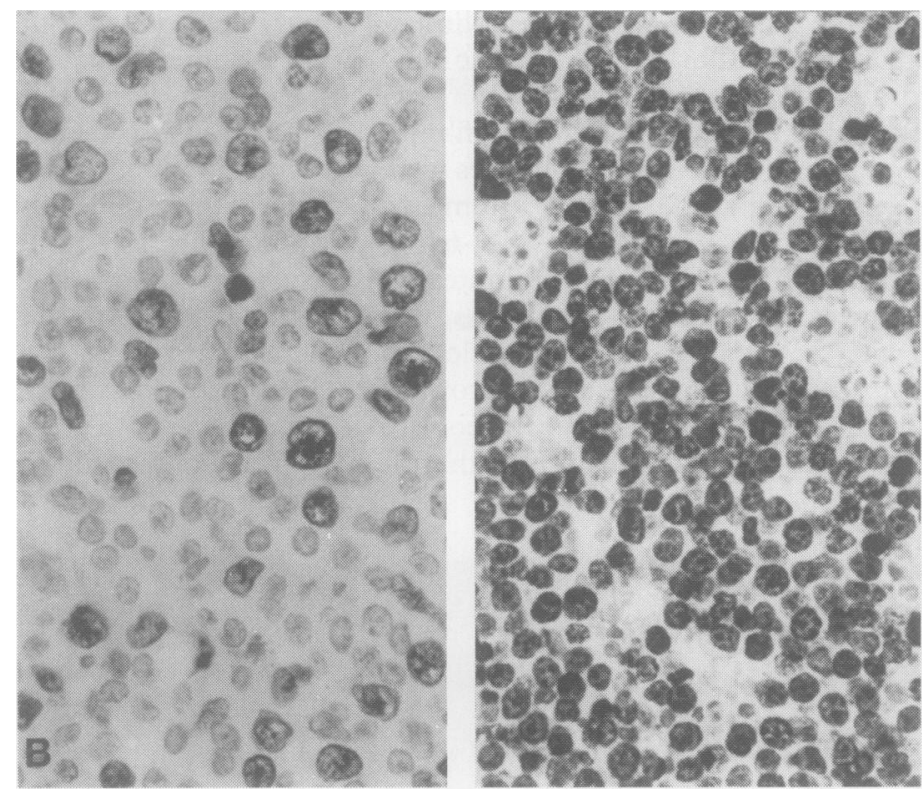

standard digestion with trypsin step (eight minutes). When lymphoid tissues were studied, the proliferation marker MIB-1 was used as a positive control for the microwave step as this antibody gives reliable and reproducible staining after microwave irradiation. ${ }^{13}$ Negative control sections from which primary antibody was omitted were included in all staining runs.

\section{Results}

Of the 80 antibodies tested, microwave pretreatment resulted in high quality staining with 20 antibodies that previously produced no staining in formalin fixed, paraffin wax embedded material (table 1) (fig 1). Antibodies differed in the amount of microwave irradiation needed, but the best results were usually obtained with two or three five minute

Table 2 Antibodies previously reactive with formalin fixed, paraffin wax embedded tissue, but showing improvement after microwave irradiation

\begin{tabular}{|c|c|c|}
\hline Antibody & $C D /$ specificity & Source \\
\hline \multicolumn{3}{|c|}{ Lymphocytic and myelomonocytic markers } \\
\hline L26 & CD20 & Dako \\
\hline LN1 & CDw75 & Biotest/Clonab \\
\hline BU38 & CD23 & Binding Site, Birmingham \\
\hline PGM1 & CD68 & $\begin{array}{l}\text { B Falini, Perugia, Italy } \\
\text { and Dako }\end{array}$ \\
\hline $\mathrm{Ki} \mathrm{B3}$ & B cells & Kiel \\
\hline BCL-2 & BCL-2 protein & K Gatter, Oxford and Dako \\
\hline HB21 & CD71 & ATCC \\
\hline BerH2 & CD30 & Dako \\
\hline LeuM1 & CD15 & Becton Dickinson \\
\hline WR14 & CD43 & $\begin{array}{l}\text { Wessex Regional Immunology } \\
\text { Unit }\end{array}$ \\
\hline \multirow{2}{*}{$\begin{array}{l}\text { CD3 } \\
\text { Polyclonal } \\
\text { WR18 }\end{array}$} & CD3 & Dako \\
\hline & MHC class II & $\begin{array}{l}\text { Wessex Regional Immunology } \\
\text { Unit }\end{array}$ \\
\hline \multicolumn{3}{|r|}{ Unit } \\
\hline $\begin{array}{l}\text { HECD } 1 \\
\text { NCC-CAD }\end{array}$ & $\begin{array}{l}\text { CD44 } \\
\text { E-cadherin } \\
\text { P-cadherin }\end{array}$ & S Hirohashi, Tokyo, Japan'18 \\
\hline 299 & & \\
\hline $\begin{array}{l}\text { Hermes } 1 \\
\text { Hermes } 3\end{array}$ & $\begin{array}{l}\text { CD44 } \\
\text { CD44 }\end{array}$ & $\begin{array}{l}\text { S Jalkenen, Turku, Finland } \\
\text { S Jalkenen, Turku, Finland }\end{array}$ \\
\hline $\begin{array}{l}\text { Miscellaneous } \\
\text { DO7 }\end{array}$ & p53 protein & Dako \\
\hline Collagen IV & Collagen type IV & Dako \\
\hline Laminin & Laminin & Sigma \\
\hline Vimentin & Vimentin & Euro-Path/Bio-nuclear Services \\
\hline
\end{tabular}

cycles. Within this group the dilutions were generally similar or slightly more concentrated than those used in frozen sections.

A further 21 antibodies that already stain formalin fixed, paraffin wax embedded material showed significant improvement with microwave irradiation (table 2) (fig 2). Notably, the antibodies BerH2, CD3, and LeuM1 produced high quality staining after microwave irradiation without digestion with trypsin that would have otherwise been necessary. Many of these antibodies also produced improved staining at significantly higher working dilutions.

The remaining antibodies, of which WR17, 3.9, $\mathrm{Ki} \mathrm{M1}, \mathrm{Y} 1 / 82 \mathrm{~A}, \mathrm{UCHT} 1$, OKT3, 4, 6, and 8, HB2, UCHL1, $\beta F 1$, TCR $\delta 1$, JOVI-1 and $3, \mathrm{PC} 10, \mathrm{TS} 2 / 77$, and fibronectin are commercially available, did not show any improvement after microwave treatment. With some of these we combined microwave irradiation with a subsequent short digestion with trypsin stage, without any improvement in staining results.

\section{Discussion}

Our study has shown that paraffin wax embedded material can be successfully immunostained using antibodies that were previously reported to stain only frozen tissues. Therefore, the number of antibodies available for the study of archival material can be greatly increased.

Microwave irradiation offers several advantages for routine immunocytochemistry. Recent studies have shown improved staining with several antibodies after microwave irradiation. ${ }^{614}$ Many of these antibodies already stain paraffin wax embedded tissue, and our study contains further antibodies in this category. In some cases the staining quality of such antibodies is improved; in others microwave treatment may allow cost savings to be made through the use of higher primary antibody dilutions. The need for enzymatic 
Figure 2 Examples of antibodies that previously showed some reactivity in formalin fixed, paraffin wax embedded material, and gave much improved staining after microwave pre-treatment. (A) Hermes 3 , with (right) and without (left) microwave pre-treatment (thyroid). (B) p53 staining in enteropathy associated T cell lymphoma (left), Burkitt's lymphoma (centre), and Hodgkin's disease (right).
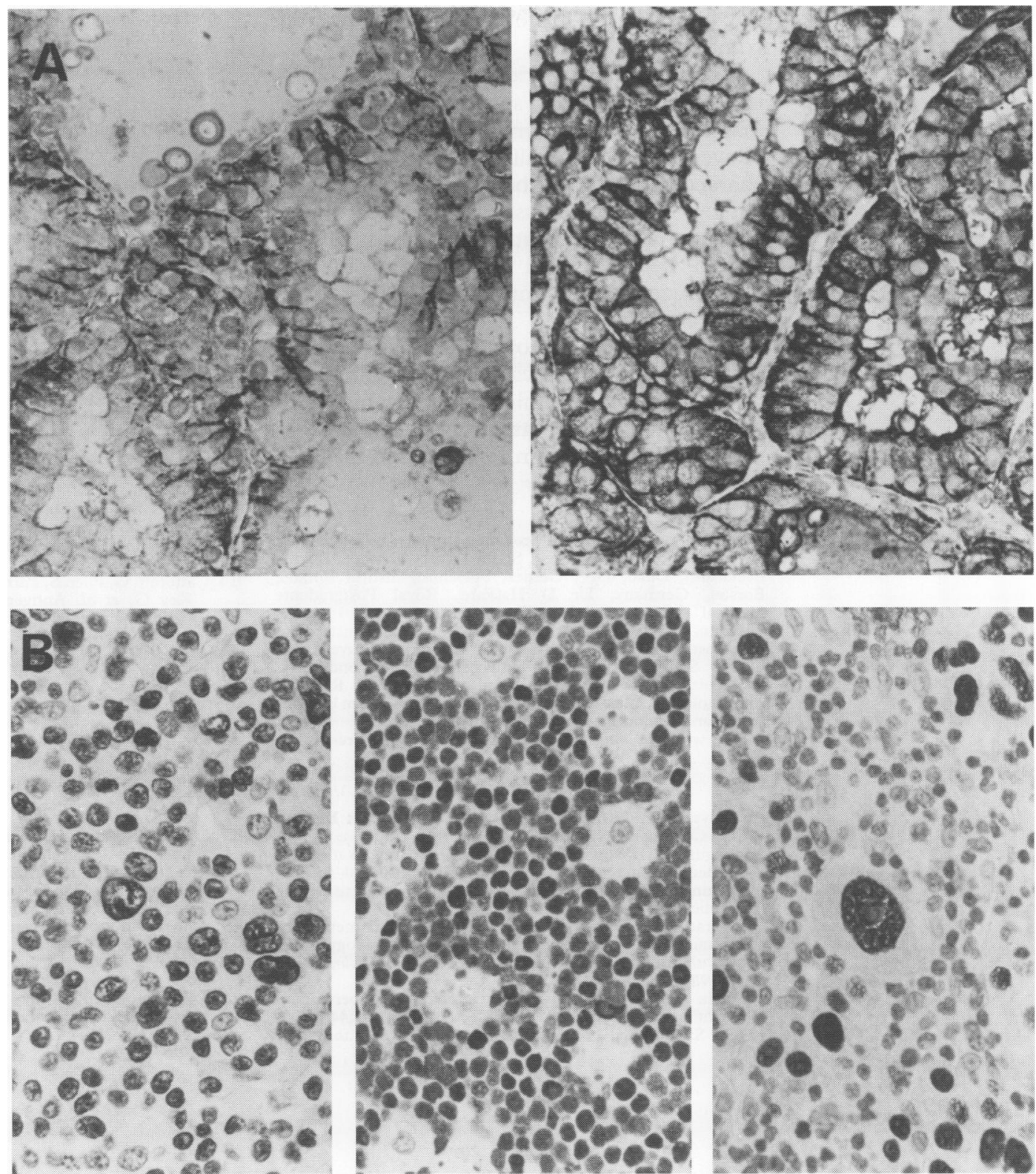

predigestion of sections is obviated in some cases. Many antibodies (such as CD3) also benefit from a reduction in background staining.

The adverse effects of microwave treatment include detachment of sections from slides during irradiation, especially with higher numbers of cycles. This most often occurs with tissues containing prominent fibrous elements (such as nodular sclerosing Hodgkin's disease), and under these circumstances may occur despite coating slides with PLL or APTS. Background staining may also occur with some antibodies, particularly with longer exposure times to microwave irradiation.

We found that, using Coplin jars, the best results were obtained when sections were placed towards one end of the slide, to ensure continual immersion in buffer solution during microwave irradiation. With this method, a maximum of 15 slides can be irradiated during each five minute microwave cycle and the jars require repeated replenishment of evaporative loss. We are currently evaluating a method for the irradiation of larger numbers of slides in an increased volume of buffer that may allow antigen retrieval with a single, longer, irradiation step.

The mechanism of antigen retrieval achieved by microwave irradiation remains obscure, but a possible explanation is that microwaves disrupt the cross-linking of proteins in a similar way to that achieved by enzymatic predigestion. ${ }^{6}$ At present, most laboratories use domestic microwave ovens for antigen retrieval, and the characteristics of microwave delivery may vary between different ovens. This could account for differences in the reproducibility of immunostaining results between centres.

It has been suggested that a combination of protease digestion and microwave treatment may improve the staining characteristics of a small number of antibodies, such as immunoglobulin light and heavy chains. ${ }^{19} \mathrm{We}$ combined microwave irradiation with digestion with trypsin for several antibodies, but could not improve the staining quality achieved with microwave treatment alone. Additionally, tissue morphology was often 
impaired when both forms of treatment were combined.

Based on our experience with the antibodies studied, antibody specificity seems to be maintained after microwave treatment. However, the possibility of altered staining characteristics should be considered whenever antigen retrieval is used with new or previously untested antibodies, and results should be compared with those obtained using frozen section immunohistochemistry in initial evaluation.

In conclusion, microwave irradiation represents a major technical advance, enhancing tissue antigenicity while preserving morphology. It is straightforward to perform, and has wide application within research and diagnostic histopathology.

We thank the following for providing primary antibodies: $\mathrm{Dr}$ D Anstee, Blood Services South West, Bristol; Becton Dickinson; Dako; Dr J Gerdes, Forschungsinstitut Borstel, Borstel, Germany, Dr D Haskard, Royal Postgraduate Medical School, London; Dr S Hirohashi, Tokyo; Dr Jalkenen, Turku, Finland; Dr C Meijer, Amsterdam; Novocastra; Nuffield Department of Pathology, University of Oxford; Sigma; Dr J Spencer, University College, London; Dr A Tutt, Tenovus, Southampton; Wessex Regional advice and technical assistance.

This work was supported in part by the Coeliac Trust.

1 Mayers CP. Histological fixation by microwave heating. F Clin Pathol 1970;23:273-5.

2 Login GR, Dvorak AM. Microwave energy fixation for electron microscopy. Am ₹ Pathol 1985;120:230-43.

3 Brinn NT. Rapid metallic histological staining using the microwave oven. $\mathcal{F}$ Histotechenol 1983;6:125-9.

4 Estrada JC, Brinn NT, Bossen EH. A rapid method of staining ultrathin sections for surgical pathology TEM with the use of the microwave oven. Am 7 Clin Pathol 1985;83:639-41.

5 Chiu KY. Use of microwave for rapid immunoperoxidase staining of paraffin sections. Med Lab $S_{c i} 1987 ; 44: 3-5$.

$6 \mathrm{Shi}$ SR, Key ME, Kalra KL. Antigen retrieval in formalin- fixed, paraffin-embedded tissues: An enhancement method for immunohistochemical staining based on microwave oven heating of tissue sections. $\mathcal{F}$ Histochem microwave oven heating
Cytochem 1991;39:741-8.

7 Gerdes J, Becker MHG, Key G, Cattoretti G. Immunohistological detection of tumour growth fraction (Ki-67 antigen) in formalin-fixed and routinely processed tissues. $\mathcal{F}$ Pathol 1992;168:85.

8 Cattoretti G, Becker MHG, Key G, Duchrow M, Schluter $\mathrm{C}$, Galle J, et al. Monoclonal antibodies against recombinant parts of the $\mathrm{Ki}-67$ antigen (MIB 1 and MIB 3) detect proliferating cells in microwave processed form lin-fixed paraffin sections. $\mathcal{F}$ Pathol 1992;168:357-63.

9 Mason DY, Cordell JL, Gaulard P, Tse AGD, Brown MH. Immunohistological detection of human cytotoxic/suppressor T cells using antibodies to a CD8 peptoxic/suppressor T cells using antibodies to a

10 Sawhey N, Hall PA. Ki-67-structure, function and new antibodies. Editorial. $₹$ Pathol 1992;168:161-2.

11 Mepham BL, Frater W, Mitchel BS. The use of proteolytic enzymes to improve immunoglobulin staining by the PAP technique. Histochem $\mathcal{F} 1979 ; 11: 345-58$.

$12 \mathrm{Hsu}$ SM, Raine L, Fanger H. Use of avidin-biotin-peroxidase complex $(\mathrm{ABC})$ in immunoperoxidase techniques: a comparison between $\mathrm{ABC}$ and unlabelled antibody (PAP) procedures. 7 Histochem Cytochem 1981;29: 577-80.

13 Cuevas E, Jones DB, Wright DH. Immunohistochemical detection of tumour growth fraction (Ki-67 antigen) in formalin-fixed and routinely processed tissues. $¥$ Pathol 1993;169:477-8.

14 Cattoretti G, Pileri S, Parravicini C, Becker MHG, Poggi S Key $G$, et al. Antigen unmasking on formalin-fixed, paraffin embedded tissue sections. F Pathol 1993;171: 83-98.

15 Anstee DJ, Gardner B, Spring FA, Holmes CH, Simpson $\mathrm{KL}$, Parsons SF, et al. New monoclonal antibodies in $\mathrm{CD} 44$ and CD58: their use to quantify CD44 and CD58 on normal human erythrocytes and to compare the distribution of CD44 and CD58 in human tissues. Immunology 1991;74:197-205.

16 Garrido MC, Cordell JL, Becker MHG, Key G, Gerdes J, Jones $M$, et al. Monoclonal antibody JC1: New reagent Jones $M$, et al. Monoclonal antibody J $860-5$.

17 Gerdes J, Lemke H, Baisch H, Wacker HH, Schwab U, Stein $\mathbf{H}$. Cell cycle analysis of cell proliferation-associated human nuclear antigen defined by the monoclonal antibody $\mathrm{Ki}-67$. F Immunol 1984;133:1710-5.

18 Shimoyama Y, Hirohashi S. Expression of E- and P-cadherin in gastric carcinomas. Cancer Res 1991;51. 2185-92.

19 Merz H, Rickers O, Schrimel S, Orscheschek K, Feller AC. Constant detection of surface and cytoplasmic immunoglobulin heavy and light chain expression in formalin fixed and paraffin embedded material. $\mathcal{F}$ Pathol 1993;170:257-64. 